\title{
The Politics of Oil in Venezuela
}

Franklin Tugwell. A case study of the relationship between foreign oil corporations and the state in Venezucla, this book focuses on the strategies adopted by Venezuelan leaders to control the behavior of the world's largest and most powerful multinational corporations. Among the main themes of the book are the pattern of bargaining and conflict between the government and the oil companies; the impact of ideology upon the selection of alternative courses of action; and the interdependence of the domestic political process, petroleum policy, and rapid social change. $\$ 8.95$

\section{Stanford University Press}

\section{UNDERSTANDING WORLD POLITICS}

Kenneth W. Thompson centers this book on the question of ends and means in politics and offers a new set of concepts and conclusions on morality and politics. He provides a general framework for thinking about world politics.

320 pages

\section{DIPLOMACY AND REVOLUTION: The Soviet Mission to Switzerland, 1918}

Alfred Erich Senn relates the formation and operation of an early Soviet diplomatic mission to the development of Bolshevik foreign policy.

224 pages 